\title{
Д.И. САЗОНОВ
}

\section{«РЕЛИГИОЗНОЕ ДИССИДЕНТСТВО॥ КАК ЯВЛЕНИЕ

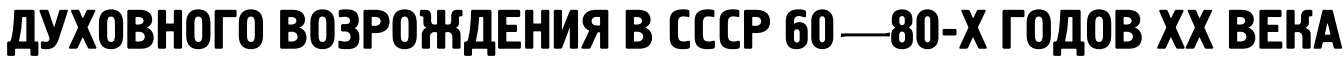

Исследуется феномен «религиозного диссидентства» в СССР в 60-80-е годы XX века. Средой, в которой возникло диссидентство, стала интеллигенция, которая в 60-х годах начала открывать для себя русскую духовную культуру. Через духовные искания образованные люди пришли в Церковь, нашли Бога, и не смогли смириться с давлением государства, провозгласившего своей идеологической платформой атеизм и борьбу против религии, что проявилось в закрытии храмов, запрещении свободного проявления религиозных чувств, в подавлении прав и свобод личности и т. д.

Ключевые слова: религиозное диссидентство, духовное возрождение, интеллигенция, атеизм, верующие, культура.

B эпоху «хрущевской оттепели» (середина 1960-х) в светской среде возникло диссидентское движение. Одним из его направлений стало «религиозное диссидентство», главной целью которого было восстановление религиозной свободы, прекращение преследования людей по религиозным соображениям, прекращение вмешательства спецслужб в жизнь Церкви.

В СССР на рубеже 50-60-х годов атмосфера была такой, что, по словам С.С. Аверинцева, верующий выглядел «безумцем в глазах окружающих» [1]. Под «окружающими» подразумевалось не только партийное начальство, но и большинство населения страны. Однако к концу 1960-х годов даже профессиональные атеисты признавали, что в СССР произошел подъем религиозности. Религиозное возрождение 60-80-х годов повторило послевоенное религиозное возрождения 1946-1956 годов. Однако отличительной чертой религиозного возрождения 60-х стал яркий политический контекст, несогласие людей мириться с подавлением свободы личности и несправедливостью общественного положения верующих в социалистическом государстве. Было и еще одно отличие, а именно то, что в хрущевско-брежневский период духовные искания интеллигенции привели ее часть в Церковь. Если в послевоенное время представители интеллигенции терялись в огромной массе «простого народа», то среди новообращенных в 60-80-е года доминировали представители интеллигенции.

Масштабы религиозного возрождения этого времени не вполне ясны и по сей день. Процесс возрождения, конечно же, был ограниченным и охватывал главным образом молодую городскую интеллигенцию, но именно то, что в него оказалась вовлеченной интеллигенция, сделало его заметным в жизни советского общества.

Партийные идеологи того времени называли несколько причин, способствовавших «выживанию» религии в СССР: религиозные передачи зарубежного радио; незаконный ввоз из-за границы религиозной литературы на русском языке; усилия духовенства по привлечению молодежи путем придания Церкви роли хранительницы национальных духовных ценностей. Эти факторы «работали» на обращение к вере, в первую очередь, представителей интеллигенции.

Атеизм хрущевского периода не был исключительно партийной установкой. Он соответствовал духу эпохи. На рубеже 50-60-х годов в стране получила распространение идея преображающего мир прогресса в связи с охватившей общественное мнение эйфорией по поводу возможностей прогресса как двигателя науки. Отметим, что для начала 60-х в СССР характерен настоящий культ науки. Научное знание противопоставлялось в глазах интеллигента идеологическим штампам «научного коммунизма» и было выходом творческих сил и энергии из тисков мертвящей и давлеющей партийной идеологии. Культ науки подкреплялся реальными достижениями советских ученых. Развитию целых интеллектуальных сообществ способствовали возникшие новые научные центры и академгородки - Дубна, Новосибирск, Красноярск, Якутск. Сильным аргументом в пользу прогресса и достижений науки были достижения страны в освоении космоса. Несовместимость религии с прогрессом и современной наукой представлялась очевидной для большинства молодых людей 60-х годов. В свете бытующего мировоззрения вера в Бога противопоставлялась не столько Советской власти, сколько науке и просвещению.

Однако вера в прогресс оказалась недолгой. Культ науки для думающих людей не решал проблему наличия зла в мире. Причиной тому оказалось явление культурного характера. В «хрущевскую оттепель» своего пика достигла пропаганда достижений советского строя и превосходства его перед «капиталистическим Западом». В целях рекламы достижений социализма и формирования имиджа страны за рубежом востребованной оказалась русская культура, немыслимая без своих религиозных основ. Зарубежные поездки артистов кино и театра, обмен выставками произведений искусства не только сыграли значительную роль в ознакомлении Запада с достижениями Советского Союза, но и выявили значительный интерес к подлинно русской культуре как 
за рубежом, так и внутри страны. Возникает мода на коллекционирование икон, в конце 60-х выходят произведения, посвященные русской религиозной и духовной культуре и традициям: романы В. Солоухина «Черные доски», 0. Гончара «Собор», А. Солженицына «Матренин двор», а также фильмы А. Тарковского «Андрей Рублев», Я. Лапшина «Угрюм-река», документальное кино, посвященное зодчеству и архитектуре русского Севера и Золотого кольца. Большую роль в возрождении интереса к культуре Древней Руси сыграли труды академика Д.С. Лихачева, открывавшие оторванному от вековых традиций советскому интеллигенту целые пласты еще недавно подвергавшиеся забвению истории страны, обычаев и традиций народа. Существенную роль в деле духовного пробуждения сыграли и труды искусствоведов, посвященные русской иконе, архитектуре, письменности.

Необходимо отметить, что достижения культуры 60-х связаны, конечно, не с попыткой восстановления разорванных традиций, но с прорывом молодых интеллектуалов в духовное измерение. С ослаблением «железного занавеса» в СССР стала активно поступать зарубежная и эмигрантская литература. Произведения религиозного характера составили существенную долю в «самиздате». От упрощенного черно-белого взгляда на мир перед советским человеком предстал многогранный мир духовной красоты и глубины. Самиздат изменил мировоззрение советского интеллигента. В его сознании постепенно утверждалось понимание, что вера в Бога вполне совместима с образованностью и самостоятельностью мышления [2, с.13]. «Застой» поздних 60-70-х годов показал окончательную несостоятельность коммунистической идеи и определил поиск альтернативных путей духовного поиска, одним из которых могло быть обращение к христианству. Один из самых компетентных советских религиоведов П.К. Курочкин в монографии «Эволюция современного русского православия» (1971) отмечал небольшое, но постепенно возраставшее число молодых выходцев из интеллигенции, становившихся священниками (См.: [3, с. 511]). Придя в духовные учебные заведения, эти люди способствовали выходу Церкви из границ того «гетто», в которое советский режим старался заключить Церковь. В числе таковых можно назвать протоиерея Александра Меня, священника Глеба Якунина.

Зарубежная, в том числе эмигрантская религиозная литература начала активно поступать в СССР еще с конца 50-х годов. Большое значение имело распространение так называемого «религиозного самиздата», содержательным наполнением которого были не только оригинальные статьи авторов, но и значительное число переводов и рефератов. Издавались информационные бюллетени, освещающие факты гонений за веру, воззвания, открытые письма и др. Появились периодические издания. В $1971-$ 1974 годах выходил журнал «Вече» ${ }^{1}$, выражавший русское

\footnotetext{
${ }^{1}$ «Вече»- самиздатский журнал православно-патриотического содержания (позиционировался авторами как «русский неподцензурный машинописный православный патриотический журнал»).
}

национальное самосознание, в котором видная роль отводилась Православию. Традиции «Вече» продолжили периодические издания «Земля», «Московский сборник». К середине семидесятых до половины самиздата создавалось верующими. Оживился и интерес к русской религиозной философии в лице таких ее представителей как В.С. Соловьев, А.Ф. Лосев, священник Павел Флоренский. Поскольку какая-либо проповедь за пределами храма была под запретом, то миссия и духовное просвещение в СССР тоже оказывались формой диссидентской деятельности. Произведения о. Александра Меня, о. Сергия Желудкова, переводы текстов зарубежных христианских писателей (например, Клайва Льюиса) вплоть до 90-х годов ходили только в самиздате или печатались за рубежом, и их распространение и хранение уже попадало в разряд противоправной деятельности.

Одним из источников обращения людей к вере стали уцелевшие после репрессий монахи и монахини, живущие в миру. Они, дожившие до 1960-х годов, способствовали передаче веры молодому поколению. Важную роль играло знакомство с уцелевшими в лагерях исповедниками веры - такими, как архимандрит Таврион (Батозский), архимандрит Павел (Груздев), архимандрит Севастиан (Фомин), архимандрит Борис (Холчев) и многие другие, вокруг которых вплоть до их кончины собиралось множество ищущих веры людей различных слоев общества. Много среди их духовных чад было и представителей интеллигенции [4, с. 247].

Хотя во всех высших учебных заведениях обязательным был курс атеизма, среди ученых и вузовских преподавателей находились люди, которые не только сами были верующими, но не боялись проповедовать христианство учащейся молодежи. Так, в среде интеллигенции были широко известны имена профессора военно-инженерной академии Н. В. Зволинского, профессора Московского инженерно-экономического института Н.Е. Пестова и др., нескрывавших своей религиозной принадлежности. Жаждущие услышать слово о Христе сплачивались вокруг известных московских священников - протоиереев Всеволода Шпиллера, Сергия Желудкова. В этой среде было немало вузовских профессоров и ученых с мировым именем. Среди них: М.В. Келдыш, И.В. Курчатов, Л.А. Арцимович. В начале 60-х начинается миссионерская деятельность отца Александра Меня, в конце того же десятилетия начал свои, ставшие известными, миссионерские проповеди священник Дмитрий Дудко, говоривший о роли Церкви в современном обществе и призывавший видеть в Церкви нравственную силу общества. Стиль, язык, аргументация проповедей и публикаций миссионеров 60-80-х свидетельствует, что они были обращены в первую очередь к интеллигенции [1].

Отметим, что для пришедших в Церковь интеллигентов, ставших затем диссидентами, христианство было не столько возвращением к прерванной в революцию традиции, сколько путем личного духовного поиска. Многие из неофитов привносили в церковную жизнь представления, вынесенные из воспитавшей их среды, и с трудом 
находили общий язык с традиционно верующими. Они не всегда могли удовлетвориться только посещением храма и личным благочестием. Именно поэтому период конца 50-80-х годов стал временем расцвета церковного диссидентства как выражения протеста сковывавшей свободу человека системе.

Разные пути приобщения человека к вере считались советской властью противозаконными. Если само по себе не слишком афишируемое посещение богослужений не всегда влекло за собой немедленные санкции, то активная миссия, не говоря уже о распространении религиозного самиздата, попадала в разряд преследуемой политической деятельности. То есть для интеллигента из неверующей семьи часто само по себе обращение к вере уже попадало в характерную для диссидентства «парадигму протеста». В эту же «парадигму протеста» укладывались и активная проповедь христианства и, тем более, противостояние государственному атеизму. Конечно, многим импонировал образ «глашатаев свободы», трибунов и борцов, однако нельзя не признать, что многие из новообращенных были искренни в своих порывах и в миссионерском горении. Контекстом создания диссидентского движения в целом явилось интеллектуальное брожение конца 50-60-х, породившее особую социокультурную общность. Духовные поиски, приведшие к православному возрождению, и собственно диссидентство как противостояние режиму, были в равной степени порождены этим брожением. Поэтому между ними неизбежно возникли точки пересечения, хотя православные диссиденты были лишь одной из составляющих диссидентского движения, и, естественно, далеко не все из обратившихся к Церкви в эти годы оказывались в рядах диссидентов.

Одним из направлений деятельности диссидентов было отстаивание перед государством прав на свободу совести. Диссиденты, которые были «на слуху», священники Глеб Якунин и Николай Эшлиман, мирянин Лев Регельсон не побоялись объявить о несправедливости отношения советского строя к верующим в своем открытом письме, которое называлось «К пятидесятилетию восстановления Патриаршества». Первоначальный вариант письма подготовил знаменитый публицист А.Э. Краснов-Левитин. Затем проект существенно переработали Николай Эшлиман и Георгий Эдельштейн. Над письмом работали миряне Феликс Карелин, Лев Регельсон, Виктор Капитанчук. В письме были приведены факты незаконных закрытий храмов. Главным тезисом письма было соглашательство и следование руководства Церкви всем антирелигиозным инициативам государства. Сначала предполагалось, что это будет совместное письмо епископата и священства Патриарху, но в итоге его подписали лишь двое священников. Копию письма разослали всем правящим архиереям, а также Председателю Верховного Совета СССР. Ярким представителем и знаменем протестного движения, направленного на защиту интересов Церкви, стал архиепископ Ермоген (Голубев), который вел переписку, не страшась давать в ней оценки происходящему. За свою деятельность, «вредную для Церкви», архиепископ был отправлен в Жировицкий монастырь [5, с. 2-3]. Среди самых заметных событий диссидентского движения можно назвать письмо А.И. Солженицина по поводу положения Церкви и состояния свободы совести.

Итогом действий церковных диссидентских групп, хотя оно и было небольшим по своим масштабам, явилось то, что наличие протестного движения само по себе позволяло снизить давление на Церковь. Постепенно истинное положение Церкви в СССР стало известным на Западе, и там стало формироваться убеждение о религиозном притеснении в СССР, что позволило церковному руководству добиться увеличения числа епископата и поступающих в духовные образовательные учреждения, сокращения числа закрываемых храмов, а кое-где и открытия новых приходов.

Вместе с тем, при наличии тех, «кто не мог молчать» о нарушении права свободно исповедовать религию, в Церкви были люди, которые считали, что протестное движение было самопиаром. Такой точки зрения придерживались и свою позицию озвучивали протоиерей Всеволод Шпиллер, архимандрит Сергей Савельев, которые резко раскритиковали статью Солженицина. Ярославский архиепископ Иоанна (Венланд) и протоиерей Борис Старк негативно высказались по поводу письма священника Глеба Якунина [6, с. 28]. В этой связи показательно письмо митрополита Крутицкого и Коломенского Ювеналия заместителю генерального секретаря Всемирного Совета Церквей доктору Конраду Райзеру по поводу судебных процессов в СССР над религиозными диссидентами: «К сожалению, многие стороны жизни нашего общества, включая права человека и особенно вопросы религиозной свободы, западными религиозными агентствами подаются часто весьма искаженно, в духе так называемой психологической войны. Отсюда не удивительно превратное, как правило, их толкование за границей...» [7, с. 185].

Кроме политического противостояния атеистической системе другой формой протеста церковных диссидентов стала апология исходящей от властей атеистической пропаганде, что сыграло свою положительную роль. В частности, властями широко пропагандировался опыт священнослужителей-отступников, и потому очень важно было дать адекватный ответ. С конца 50-х годов в самиздате ходило открытое письмо священника Сергия Желудкова бывшему священнику-ренегату Дарманскому. Примерно в то же время начали активную борьбу с государственной антирелигиозной пропагандой А.Э. Краснов-Левитин и его соратник В. Шавров.

В 1974 году независимо друг от друга возникли религиозно-философские семинары в Москве (под руководством А. Огородникова) и в Ленинграде, участники которых не просто собирались для обсуждения религиозных вопросов, но пытались создать христианские коммуны. В конце 70-х годов члены этих групп были осуждены «за тунеядство», поскольку сама идея активной общественной организации, существующей независимо от власти, оказалась неприемлемой для властей. 
Создание в 1973 году «Христианского комитета защиты прав верующих в СССР» во главе с Глебом Якуниным свидетельствовало о том, что ситуация в стране и в Церкви все же менялась в связи с ростом сопротивления антицерковной политике. Верующие многих приходов обращались в Комитет, который направлял затем их петиции Патриарху и гражданским властям. Встречались и более радикальные формы религиозного диссидентства, когда его участники ставили перед собой политические цели. В 1964 году был основан и просуществовал три года Всероссийский социал-христианский союз освобождения народа, которым руководили выпускники Ленинградского университета И.В. Огурцов, Е.А. Вагин, М.Ю. Садо. Союз был, по сути, первой в советский период подпольно возникшей политической партией, ставившей своей задачей свержение коммунистической власти и построение христианского государства.

В стране развитого социализма диссидентское движение было немыслимо идеологически и, конечно, подпадало под репрессивную машину государственного аппарата. В 1979 году Глеб Якунин был арестован (полученный им лагерный срок сокращен лишь в 1987 году). Разгромлены религиозно-философские семинары в Москве (Александр Огородников), Ленинграде (Виктор Пореш), Смоленске (Татьяна Щипкова), организаторы семинаров получили длительные сроки. Священник Дмитрий Дудко за свою просветительскую деятельность в начале 1980 года был арестован, после полугодового следствия выступил по Центральному телевидению с заявлением, что действовал по заданию ЦРУ, раскаивается и в будущем воздержится от любой политической деятельности. После выступления он был освобожден и получи приход [8, с. 167].

В 1970 году протоиерей Павел Андельгейм был осуждён на три года лагерей по обвинению в «клевете на советский строй». На процессе в Ленинградском городском суде в апреле1980 года подследственный В. Пореш заявил: «В 1974 году нами был создан Христианский семинар по проблемам религиозного возрождения в России. С самого начала, с создания, семинар подвергался преследованиям КГБ. Был посажен в психиатрическую больницу член семинара А. Ардентов, его история болезни есть в деле, из нее явствует, что он абсолютно здоров. Органами осуществлялась постоянная слежка за членами семинара» [7, с. 182]. В 1966 году двенадцать верующих Кировской епархии подписались под письмом протеста против закрытия храмов, которое было направлено Патриарху. Письмо составил математик Б. Таланов, арестованный за свои убеждения и умерший в тюрьме в 1971 году. В письме, получившем огласку и за пределами страны, говорилось о том, что религиозная жизнь разоряется руками церковного руководства [4, с. 48- 49]. Таланов не только бесстрашно критиковал власти в разгар хрущевских гонений, но и опубликовал в 1967 году в самиздате статью «Сергиевщина или приспособленчество к атеизму», где утверждал, что компромисс с советской властью не выполнил задачи сохранения Церкви, но превратил Мо- сковскую патриархию в послушное орудие атеистической власти.

В отчете об итогах организационной и агентурнооперативной деятельности 4-го (церковного) отдела 5-го управления КГБ за 1982 год сообщалось число репрессированных за «церковное» диссидентство: «В настоящее время по стране за конкретные преступления отбывают наказания 229 церковников и сектантов (в 1981 году 220). Кроме того, 18 человек находится в ссылке (в 1981 году - 24). Органами КГБ на враждебных элементов из этой категории граждан велось свыше 2500 дел оперативного учета (в 1981 год - 2225) [9, с. 398]. Протестное движение повлекло не только репрессивные меры со стороны светских властей, но и меры прещения со стороны властей церковных. И хотя основной огонь критики религиозных диссидентов был направлен на Советскую власть, однако, поскольку за все время существования при Советской власти руководству Православной Церкви неоднократно приходилось идти на многочисленные компромиссы, деятельность церковных диссидентов неизбежно входила в конфликт и с руководством Патриархии. Авторы поплатились за свое письмо запретом в служении.

Деятельность религиозных диссидентов пережила подъем в первой половине 1970-х, после чего последовал спад под ударами КГБ. Рубеж 70-х и 80-х был ознаменован арестом многих диссидентов, в том числе и из церковной среды, усилением давления на авторитетных и независимых священников. Однако наряду с преследованиями независимо мыслящих людей коммунистические власти стали сами задумываться о смене идеологической парадигмы. На смену окончательно обанкротившейся коммунистической идее все более явно выдвигалась на первый план имперская, националистически окрашенная идеология, в которой определенная роль, по замыслу партийных идеологов, могла отводиться и Православной Церкви. Противостояние коммунистической власти, в том числе и в виде обращения к вере, объединяло людей самых разнообразных, порой противоположных взглядов. Если в проповедях о. Александра Меня всегда подчеркивался вселенский характер христианства, то другим, противоположным и очень влиятельным направлением мысли независимой интеллигенции, имевшим сильное влияние на членов Церкви, был русский национализм. Националисты считали, что нравственными и духовными ценностями русского народа на протяжении его истории были ценности православия, и их следует возродить. Это направление было также весьма неоднородным - наряду с любителями русской старины, видными деятелями культуры внутри этого движения были и антисемиты, сталинисты, сторонники «Великой России» как военно-промышленной империи, и между «темным» и «светлым» в русском национальном движении не могло быть четкого водораздела. Смерть Андропова, борьба за власть в верхушке КПСС и углубляющийся кризис на время отодвинули эти планы. 
Оценка протестного движения в СССР позволяет сделать вывод о том, что процесс религиозного возрождения 60-70-х годов не просто совпал по времени с появлением диссидентского движения в СССР, но был, как и это движение, порожден кризисом и разложением официальной коммунистической идеологии. Частичное совпадение этих процессов привело к тому, что, благодаря «церковным диссидентам» кризисные явления в самой Церкви стали предметом обсуждения уже не только среди ее служителей. Наряду с политикой властей СССР эти явления стали обсуждаться в кругах интеллигенции, близких к диссидентскому движению. Таким образом, приходилось «сражаться на два фронта» - с властями светскими и властями церковными, причем репрессии могли грозить им с обеих сторон.

Русское общество, давно лишенное христианской подпитки, оказывалось больным нравственно и нетерпимым политически. Многие из тех, кто справедливо обличал коммунистов за разрушение русской культуры, общества, за уничтожение Церкви, оказывались такими же идеологами нетерпимости, проповедуя авторитаризм, насилие и ненависть к «инородцам» и «иноверцам». Примером тому может служить судьба отца Дмитрия Дудко, который после падения Советской власти публиковал свои статьи в газете «Завтра», где состоял духовником.

Сегодня можно сказать, что многие нынешние конфликты в Церкви берут свое начало в 60-70-х годах, в разных направлениях мысли интеллигентов, обратившихся к вере. С одной стороны, в это время оказалась возможной встреча уцелевших исповедников веры - современников церковного возрождения начала века с новым поколением людей, пришедших в церковь. С другой уже были заложены истоки сегодняшней тенденции в Церкви, когда в православии стали видеть идеологию, замену обанкротившемуся «единственно правильному учению». Отражением этого кризиса стал феномен церковного диссидентства. И хотя сам феномен остался в прошлом, защита Церкви от государственной власти продолжает оставаться актуальной и сегодня - как противостояние уже не государственному атеизму, но неоимперской идеологии, облекаемой в церковные одежды.

Год 1000-летия Крещения Руси стал переломным для церковно-государственных отношений. Новый взгляд по отношению к Церкви со стороны государства был вы- ражен словам: «Советский Союз не является режимом, преследующим религию. Но это страна, в которой и атеисты, и верующие совместно строят социализм» [8, с. 72]. В своем выступлении на XIX Всесоюзной партконференции Генеральный секретарь КПСС М.С. Горбачев сказал: «Мы не скрываем своего отношения к религиозному мировоззрению как нематериалистическому, ненаучному. Но это не основание для неуважительного отношения к духовному миру верующих людей и тем более применения какого бы то ни было административного давления для утверждения материалистических воззрений. Все верующие, независимо от того, какую религию они исповедуют, являются полноправными гражданами СССР <...> Готовящийся сейчас проект закона о свободе совести основывается на ленинских принципах, учитывает все современные реальности» [10, с.41-42]. Празднование 1000-летия Крещения Руси стало не только церковным и религиозным событием, но и резонансным явлением общественно-политической жизни как внутри страны, так и за ее пределами. Эта перемена стала возможной, в том числе, и благодаря деятельности людей, которые не побоялись отстаивать свои убеждения, тех, за которыми уже прочно утвердилось название - диссиденты.

\section{Список литературы}

1. Аверинцев С. Миссионер для племени интеллигентов // Литературная газета. - 1991. - 4 сент.

2. Эдельштейн Г., прот. Записки сельского священника. M., 2005.

3. Поспеловский Д.В. Русская Православная Церковь в XX веке. - М.: Республика, 1995.

4. Архимандрит Павел (Груздев). - М.: Отчий дом, 2006.

5. Журнал Московской Патриархии. - 1969. - № 4.

6. Государственный архив Ярославской области (ГАЯО). Ф. Р-1033. 0п.1. Д. 70.

7. Русская Православная Церковь в советское время. Материалы и документы по истории отношений между государством и Церковью / сост Г. Штриккер. Кн.2. - М., 1995.

8. Русская Православная Церковь в советское время. Материалы и документы по истории отношений между государством и Церковью / сост Г. Штриккер. Кн. 1. - М., 1995. - С. 72.

9. Шкаровский М.В. Русская Православная Церковь в XX веке. - М.: Вече; Лепта, 2010.

10. Материалы XIX Всесоюзной конференции Коммунистической партии Советского Союза. - М., 1988. 